\title{
Professional versus Social Media: News Credibility and Impact
}

\author{
Hadiza Wada \\ Kaduna State University, Kaduna, Nigeria, Hadiza.wada@kasu.edu.ng
}

\begin{abstract}
This study's relevance lies in its goal of ascertaining the degree to which people rely on unprofessionally processed information in (1) making vital decisions or (2) acting on unsubstantiated information served via social media. In addition, it measures the audiences' ability to differentiate information emanating from professional, versus social media. Professional media, in this case, refers to the traditional broadcast and print media who have been in the business of professionally processing and authenticating news and information for their respective audiences. While social media, on the other hand, represent the various platforms provided primarily for social exchange of information. Relevant to this study is the social media's ability to reach multitudes of people with unprocessed and uncertified information that can go viral, reaching millions of people. The theoretical framework is Uses and Gratification Theory, UGT, and the methodology is random survey.
\end{abstract}

KEYWORDS: Social media, traditional media, news credibility, fake news

\section{Introduction}

Professional media, sometimes referred to as traditional media has gradually become just a part of the general media world. Multimedia content provision is now the norm while social media practically invaded the media domain, providing information and media content to anyone willing to read, listen or watch. Soon traditional media establishments including conglomerates began to lose their audiences to internet users, while most joined the trend by operating blogs and incorporating social media in their live interactive programs. Scholars have studied various aspects of such relationships including its effect on programming content, delivery method and quality of what is served to the audience ultimately (Girard 2003). Some see positive impact (Pavlik 2001) when radio is converged with social media for interactivity during broadcasts, while others add that social media has consistently outscored traditional media in breaking news (Bosch 2010). Bosch further added that social media has changed ways in which news are generated and accessed. In Africa (Pavlik 2001) see only the rising impact of the internet and social media, just as the tools that provide consumers with such services continue to improve and multiply in number.

\section{Statement of the Problem}

The prevalence of social media usage, and its circulation of unverified but at times critical information is a major concern, most especially when the issue circulated borders on political stability, security, health and other matters of life and death. Scholarly articles have been written on uses of social media in recent years for social marketing and mobilization (Brown, Guskin, and Mitchell 2012), especially after the Arab Spring or mass demonstrations the world saw in several countries of the Middle East and North Africa, from Tunisia to Egypt's Tahrir Square between 2010 to 2012.

Then there is the challenge among users in discerning which piece of information is credible and which is not. Most users do not have ways of assessing the credibility of information (Edogor, Jonah, and Ojo 2015). More often than not, the source of the information is not indicated for the user, especially in the case of information shared repeatedly via a chain of networks through social media. The potential for intentional misuse of social media to spread misinformation, rumors and even fake news is also a concern. Fake news (Askew 2018) is defined as 'deliberate misinformation spread through traditional or online media,' with the word fabricated featuring in most definitions. Among the questions this study attempts to answer, therefore, is the audiences' rating of social media contents and how reliable they think it is as far as being a source of news and information. Do they think what 
they get via social media is reliable? Would they act or react to messages on social media? Have they actually acted on any information they have previously received from social media?

\section{Theoretical framework}

Uses and Gratification theory has contributed a lot to our understanding of how media contributes its quota in the lives of those that use it, i.e. its audience. Research categorized under this theory has continued to enrich our understanding of the choice and utilization of media content by the general audience. In 1969 Jay Blumler and Denis McQuail studied the United Kingdom 1964 election and categorized people's motives for watching certain political programs on television Blumler \& McQuail 1969). These audience motivations formed the foundation for their research in 1972 and led to active audience theories, better known later as Uses and Gratification Theory, UGT. The theory stresses the basic premise that audiences are not passive consumers of media content. The selectivity aspect as a branch of active listeners theory helps us analyze what audiences seek from the media, and for what reason they seek it; selective exposure. How they choose (select) content, including their psychological processing of that choice probed under selective perception, and what they seek to process and retain mentally, selective retention. And finally how they store such information mentally and use it in their lives whenever the opportunity for application arises.

\section{Related Literature}

\section{General Impact of New Media on Professional Media}

With the onset of online information and the resultant proliferation of news sources far beyond the traditional media, many studies were conducted to find out how the new media impact traditional media. A number of studies (Gauntlett 2011) foresee the culture of passive audiences or 'sit back and be told' fast diminishing, as audience involvement became the norm. Others, however (Hendy 2013) admit that the abundance of social tools for creating media content by unprofessional (amateurs) is posing serious threats to traditional media's existence and influence. Others (Bruns 2008) see new media as a positive means of contributing to the discourse, as a shift from industrial production of content towards a more collaborative engagement of communities of participants positively impacts traditional media production value chain. New media tends to extend the reach of traditional media to specialized audiences (Uzorchuku 2018), seeing the high involvement of the younger generation in conventional media activities is via social media, citing a study that shows otherwise more than $60 \%$ of younger Americans are moving away from traditional delivery systems altogether.

Another scholar (Zhang 2012) see the prevalent use of new media posing a threat to conventional media, while (Ogedi 2009) pointed at the challenges of authenticating information incorporated (allowed) into conventional media programming from social media without compromising professional standards. Apart from operating blogs, it has been reported (EBU 2011) that $60 \%$ of European public radio have Facebook accounts and $53 \%$ have twitter.

\section{Social Media and Credibility}

Social media has pervaded the life of a great majority of people across nations. From initially being accessed on desktop computers to laptops only, increased portability in the means of accessing and sharing information after it was introduced into smartphone and other mobile devices, made social media an everyday tool for not only socializing, but accessing and sharing information far and wide. As far as a means of accessing news, a study (Wakefield 2016) confirmed that $51 \%$ of people rely on social media as a news source. Other scholars (Kang 2009) have developed a 14 item credibility measurement criteria for blogs. In another study (Tandoc 2018), it was discovered that while 'participants rated news from a news organization as more credible than those shared on Facebook that occurs only when motivation is high. Tandoc concluded that 'there is no significant differences in credibility rating when motivation is low.' A relevant finding (Askew 2018) from a study in 2018 shows how respondents admit to sharing information whose credibility they could not ascertain. Askew discovered that 'most people who shared what was happening on social media never stopped 
to check the facts.' In an interesting study (Hovland \& Weiss 1951) experimenting on recall ability of respondents over perceptions of credibility, the authors found that 'at time of exposure, subjects discounted material from 'untrustworthy' sources. In time, however, the subjects tended to dissociate the content from the source with the result that the original skepticism faded and the untrustworthy material was accepted.' And it added that 'lies, in fact, seemed to be remembered better than truths.'

A study about social media and news credibility conducted in Nigeria (Edogor et al. 2015) indicated that $68 \%$ of respondents believe 'social media information is credible, while only $29 \%$ do not hold that belief. As to social mobilization through social media, a review of mobilized crowds by some scholars from Harvard University (Rogers et al 2017) explored how insights from behavioral science research can be used to develop interventions that mobilize a large number of people to perform behaviors that are costly and practically meaningless when performed by any one person. They underscored the centrality of social dimensions to human motivations to help others, exploring the interplay between social concerns and social mobilization, adding that most people have powerful psychological needs to belong, to be well regarded by others, and to see themselves as positive contributors to relevant social groups. Rogers et al posit "Such needs make most people especially responsive to social mobilization interventions that are particularly personal, entail social accountability, harness positive social norms, are identity relevant, and leverage social networks. This review has described how interventions designed to mobilize people to perform other-benefiting behaviors can create those conditions and has reviewed many new field applications of these ideas."

\section{Results and Discussions}

A random survey of 350 respondents was conducted via the use of questionnaires. The aim was to find out the degree to which people rely on unprofessionally processed information in (1) making vital decisions or (2) acting on unsubstantiated information served via social media. In addition it measured the audiences' ability to differentiate information emanating from professional, versus social media.

The data was categorized variously in ways that indicate significant information based on the studies focus. For example, it was discovered that while a higher percentage of younger people among the respondents (20-35 years) rely on social media as the only source of news than their older counterparts who supplement social media information with other news sources, the measurement for the perception of news credibility does not show much difference between ages.

There were three age ranges used, $20-35$ ( $42 \%$ of respondents), $36-50$ (35\% of respondents), and 50 and above ( $23 \%$ of respondents). The frequency of usage of social media varies significantly by age range also with $60 \%$ of $20-35$ admitting frequent use (several times a day) and $23 \%$ as occasional daily users. The more mature users $36-50$ years have $44 \%$ of its respondents at the several times a day level and $31 \%$ occasionally.

Among younger users 20-35 years 38\% say social media is their only daily source of news, while the rest say in addition to social media they listen and/or watch other sources of news. The significant difference comes with those 50years and above who also use social media occasionally ( $23 \%$ of respondents of that age) including for information. For that group, the main source of news, however, remain conventional media. A significant number of the age group visit blog sites, in addition to social media for other sources of news.

On issues of perception of credibility, all three age groups admit that they hardly check the source of information retrieved from social media, and cannot ascertain credibility. They also admit that they 'sometimes' doubt the credibility of news from social media. But all three age groups participate in sharing (forwarding) information that they admit not being able to vouch for its credibility. For $68 \%$ of them, sharing unsubstantiated news is the limit. When it comes to using or acting on the information more than $30 \%$ of the respondents admit to using health advice from social media (mostly WhatsApp groups), to forwarding and further spreading critical news and information that impacts security, political stability, etc. 


\section{Information from Social Media}

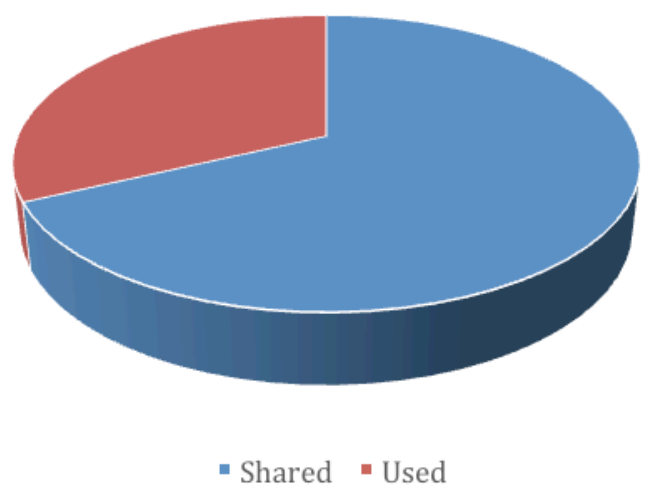

Chart 1 . Those who shared versus those who actually used/acted on social media information

On the issue of measuring the audiences' ability to differentiate information emanating from professional, versus social media. A significant percentage of the respondents do know what professional media are, while some say they even try to see whether the information comes from sources they could trust. However, whether it is the inability to discern the sources, or sheer lack of motivation to check, users are willing to use and share such information even when they cannot ascertain its credibility.

The issues regarding social media use in comparison to professional media are many, some of which are enumerated on table 1 , below.

Table 1. Traditional versus Social Media News

\begin{tabular}{|l|l|l|}
\hline No. & Traditional & Social \\
\hline 1. & $\begin{array}{l}\text { Original source of information is identified } \\
\text { with quotation marks in written reports, } \\
\text { sound bites, and pictures (television) for } \\
\text { proof of source. }\end{array}$ & $\begin{array}{l}\text { Source of information often not readily } \\
\text { available/stated. }\end{array}$ \\
\hline 2. & $\begin{array}{l}\text { Media entity responsible for news items } \\
\text { identify with their new products. }\end{array}$ & $\begin{array}{l}\text { Original source, owner or writer not } \\
\text { always disclosed. }\end{array}$ \\
\hline 3. & $\begin{array}{l}\text { Information is professionally processed } \\
\text { using journalistic standards. }\end{array}$ & $\begin{array}{l}\text { Most peddlers of news or information } \\
\text { via social media are amateurs, not } \\
\text { professional journalists. }\end{array}$ \\
\hline 4. & $\begin{array}{l}\text { News may be professionally discussed by } \\
\text { relevant professionals (Doctors, Engineers, } \\
\text { Lawyers, etc.) to assist the public in } \\
\text { forming credible opinion. }\end{array}$ & $\begin{array}{l}\text { The circle that discusses the information } \\
\text { are not necessarily professionals. }\end{array}$ \\
\hline
\end{tabular}

By Author (original), 2018

The effectiveness of social media in social mobilization and marketing (Rogers et al. 2017) has already been established by many studies and demonstrated in history (Eltantawy \& Weist 2011) mainly by the Arab Spring. In the mass revolts, the world witnessed people spontaneously mobilized for protest through the messages they shared amongst themselves on social media platforms. With that in mind, the implications for attaching credibility to non credible news should be of concern to any nation. Misleading health information can cause disease and death, misleading social information can cause upheavals and chaos; misleading economic information can cause misjudgments in investment decisions, buying, spending etc., 
In addition to bits and pieces of news and information professionally processed, then provided to the public by the traditional media, they also engage in what is generally categorized in programming as current affairs. In short, the professional media does not just inform the public about what is happening around them, they usually provide a forum of credentialed members of the community for discussing important events as they occur.

\section{Conclusion}

This study exhibits the various habits of social media users regarding the uses and gratification they receive from social media, most especially those related to news and information. It indicates the shift from conventional to social media for the younger aged Nigerians. Also, a significant number of younger Nigerians tend to source their news from social media only, while the older generation supplement those sources with other sources of news they choose. It, however, confirmed the fears of this author that most users of social media may not necessarily take the time to confirm the credibility or authenticity of a news item before they use, share or act on it. With Nigerian statistical categorization by its census board including in many other countries indicating a larger youth population, the trend where youths rely solely of social media as news and information source should be of great concern.

\section{References}

Askew, Lauren. 2018. "Can We Trust Social Media as a News Source?” Miappi, March 1, 2018.

Blumler, Jay and Dennis McQuail. 1969. Television in Politics: Its Use and Influence. University of Chicago Press.

Bosch, Tanja. 2013. "Social Media and Community Radio Journalism in South Africa." Digital Journalism, Vol. 2, 2014, Pp 29-43.

Brown, Guskin, and Amy Mitchel. 2012. "The Role of Social Media in the Arab Uprisings." Journalism and Media, November 12, 2012.

Bruns, Axel. 2008. The Future is User-led: The Path towards Widespread Produsage. New York: Peter Lang Publishing, Inc.

EBU. 2011. Public Radio and New Media Platforms. Ginevra: EBU Press.

Edogor, I.O., Jonah A., and Ojo, I. 2015. Nigerian User's Evaluation of Credibility of Social Media Sites, New Media and Mass Communication, Vol 40, 2015, pp 140-150.

Eltantawy, Nahed and Julie Weist. 2011. Social Media in the Egyptian Revolution: Reconsidering Resource Mobilization Theory. International Journal of Communication, Vol 5.

Gauntlett, David. 2011. Marketing is Connectivity. Cambridge: Polity Press.

Girard, Bruce. 2003. The One to Watch: Radio, New ICTS, and Interactivity. Rome: Food and Agricultural Organization of the United Nations.

Hendy, David. 2013. Public Service Broadcasting. New York: Palgrave-McMillan.

Hovland, and Walter Weiss. 1951. The Influence of Source Credibility on Communication Effectiveness. Public Opinion Quarterly 15(4): 635-650.

Kang, Minjeog 2010. Measuring Social Media Credibility: A Study on a Measure of Blog Credibility. Public Relations Institute.

Ogedi, Nyekwere. 2009. Influence of New Media Technology on Broadcasting: A study of television stations in Port Harcourt metropolis. Unpublished Master's Thesis, University of Nigeria, Nsukka.

Pavlik, John. 2001. Journalism and New Media. New York: Columbia University Press.

Tandoc, Edson. 2018. "Tell Me Who Your Source Is: Perceptions of News Credibility on Social Media." Journalism Practice, January 12, 2018.

Rogers, Todd, Noah Goldstein and Craig Fox. 2017. Social Mobilization, Annual Review of Psychology, Vol 13, 44.

Uzorchuku, Chioma. 2018. Online Newspaper and the Future of Print Media in Nigeria, Unpublished Master's Thesis, Bayero University, Nigeria.

Wakefield, Jane. 2016. “Social Media Outstrips TV as News Source for Young People.” BBC, June 12, 2016.

Zhang, Sheng. 2012. The Convergence of Conventional Media and New Technology in the Cases of New York Times and National Broadcasting Company (NBC), Unpublished Master's Thesis, Southeast Missouri State University, Carbondale. 